\title{
Foraging behaviour of honey bees in niger flowers, Guizotia abyssinica Cass. in North Zone of Chhattisgarh
}

\author{
G.P. PAINKRA* AND S.S. SHAW ${ }^{1}$
}

I.G.K.V., R.M.D. College of Agriculture and Research Station, Ambikapur, SURGUJA (C.G.) INDIA

${ }^{1}$ Department of Entomology, College of Agriculture, Indira Gandhi Krishi Vishwavidyalaya, RAIPUR (C.G.) INDIA

\section{ARITCLE INFO}

Received : 27.07 .2015

Revised : 11.02 .2016

Accepted : 25.02 .2016

KEY WORDS :

Foraging behaviour, Apis cerana indica, Apis dorsata, Apis florea, Niger

*Corresponding author:

Email: gppainkrarmd@gmial.com

\section{ABSTRACT}

The foraging activity of Apis cerana indica was found higher in first week of November 2011 and $2^{\text {nd }}$ week of December 2012 (33.83 bees $\left./ 5 \mathrm{~min} / \mathrm{m}^{2}\right)$. Its maximum visitation was found at $1100 \mathrm{hrs}\left(66.06 \mathrm{bees} / 5 \mathrm{~min} / \mathrm{m}^{2}\right)$. The maximum foraging activity of Apis dorsata was observed at $1100 \mathrm{hrs}\left(11.75 \mathrm{bees} / 5 \mathrm{~min} / \mathrm{m}^{2}\right)$ whereas, the lowest was observed at $1700 \mathrm{hrs}\left(0.50 \mathrm{bee} / 5 \mathrm{~min} / \mathrm{m}^{2}\right)$. The higher foraging activity of Apis florea was noticed at $1300 \mathrm{hrs}\left(4.00 \mathrm{bees} / 5 \mathrm{~min} / \mathrm{m}^{2}\right)$ and was found least at $0900 \mathrm{hrs}\left(0.56 \mathrm{bee} / 5 \mathrm{~min} / \mathrm{m}^{2}\right)$.

How to view point the article : Painkra, G.P. and Shaw, S.S. (2016). Foraging behaviour of honey bees in niger flowers, Guizotia abyssinica Cass. in North Zone of Chhattisgarh. Internat. J. Plant Protec., 9(1) : 102-108. 